\title{
Hydroaminomethylation of high alkenes with dual-metal catalysts in aqueous/organic biphasic system
}

\author{
Yingyong Wang, ${ }^{\text {a,b }}$ Chao Zhang, ${ }^{\text {a }}$ Meiming Luo, ${ }^{\text {aa }}$ Hua Chen, ${ }^{\text {a }}$ and Xianjun $\mathrm{Li}^{\mathrm{a}}$ \\ ${ }^{a}$ Key Laboratory of Green Chemistry and Technology of Ministry of Education at Sichuan \\ University, College of Chemistry, Sichuan University, Chengdu 610064, P. R. China \\ ${ }^{b}$ Key Laboratory of Carbon materials, Institute of Coal Chemistry, Chinese Academy of Science, \\ Taiyuan 030001, P. R. China \\ E-mail: luomm@scu.edu.cn
}

\begin{abstract}
The water-soluble rhodium and iridium dual metal catalysts, $\mathrm{RhCl}(\mathrm{CO})(\mathrm{TPPTS})_{2}$ and $\mathrm{IrCl}(\mathrm{CO})$ (TPPTS $)_{2}$ [TPPTS: $\mathrm{P}\left(m-\mathrm{C}_{6} \mathrm{H}_{4} \mathrm{SO}_{3} \mathrm{Na}\right)_{3}$ ], were used in the hydroaminomethylation of high alkenes in aqueous/organic two-phase system in the presence of the cationic surfactant cetyltrimethylammonium bromide (CTAB). Higher activity and especially better chemoselectivity for amine were achieved under milder conditions compared with the sole use of rhodium or iridium catalyst. The combination of rhodium and iridium complexes accelerated the hydroaminomethylation, while excess of iridium complexes led to a decrease of reactivity.
\end{abstract}

Keywords: Hydroaminomethylation, alkenes, rhodium, iridium, dual metal catalysts, biphasic catalysis

\section{Introduction}

As a class of important organic compounds, amines are widely applied in the chemical and pharmaceutical industries. Among various amines, long-chain amines are particularly of interest for manufacturing surfactants. The traditional synthetic routes to long-chain amines are mostly multi-step- and less atom-efficient- processes, with a number of by-products. ${ }^{1,2}$ The hydroaminomethylation of alkenes has recently attracted great attention as an atom-economically efficient one-pot synthesis of amines. The hydroaminomethylation of high alkenes in homogeneous catalysis has been investigated by Schultes ${ }^{3}$ using the $\mathrm{Rh} / \mathrm{Ru}$ catalyst. While good conversion and selectivity were achieved, the reaction conditions were severe $(10-15 \mathrm{MPa}$, $150{ }^{\circ} \mathrm{C}$ ) and the regioselectivity was low (the ratio of linear to branched amine was $0.98-1.4$ ). The biphasic catalysis has arisen in the last two decades, which simplifies the separation of catalysts from products by decantation and facilitates catalyst recycling, and has been proved to 
be industrially important. ${ }^{4,5}$ The replacement of organic solvents by water is also advantageous for the environment, safety and economy. Beller and co-workers reported hydroaminomethylation of lower alkenes ( $\leq$ C5) with ammonia with two-phase catalysis in $1999 .{ }^{6}$ In organic solvents and under high pressure $\left(120 \mathrm{MPa}, \mathrm{CO} / \mathrm{H}_{2}=1: 5\right)$, usually a mixture of primary and secondary amines was obtained in $75-90 \%$ yields after 10 hours. Recently we extended the catalytic hydroaminomethylation in aqueous/organic two-phase to high alkenes. ${ }^{7}$ Although conversion over $90 \%$ was achieved, the activity and chemoselectivity for amine remains to be developed.

In the mechanism, the hydroaminomethylation of alkenes consists of three steps (Figure 1): the initial hydroformylation of alkene, followed by the condensation of the intermediate aldehyde with a primary or secondary amine to form an enamine or imine, and then a final hydrogenation to give a saturated secondary or tertiary amine. ${ }^{8,9}$ Though rhodium complexes were efficient for hydroformylation of alkenes, they were not so active for the last hydrogenation of imine or enamine. Since iridium is known to be more active for the hydrogenation of $\mathrm{C}=\mathrm{N}$ double bonds than rhodium, ${ }^{10}$ it can be expected that using mixtures of water-soluble $\mathrm{RhCl}(\mathrm{CO})(\mathrm{TPPTS})_{2}$ and $\operatorname{IrCl}(\mathrm{CO})(\mathrm{TPPTS})_{2}$ as catalysts for aqueous/organic biphasic hydroaminomethylation of high alkenes would increase the hydrogenation activity of enamines/imines so as to improve the chemoselectivity for amines.

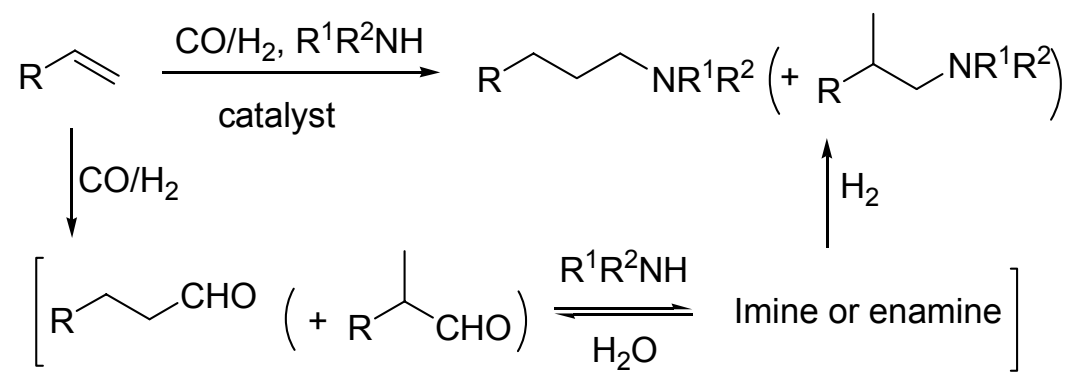

Figure 1. Hydroaminomethylation reaction of alkene

\section{Results and Discussion}

The hydroaminomethylation of 1-dodecene with synthetic gas $\left(\mathrm{CO}: \mathrm{H}_{2}=1: 1\right)$ and dimethylamine was investigated in the $\mathrm{Rh} / \mathrm{Ir} / \mathrm{TPPTS}$ biphasic catalyst system $(\mathrm{Rh} / \mathrm{Ir}=1: 1)$, and a high conversion of $94.0 \%$ and chemoselectivity of $66.8 \%$ for amines were obtained under relatively mild conditions $\left(130{ }^{\circ} \mathrm{C}, 3 \mathrm{MPa}\right)$. Obviously, the chemoselectivity for amines was greatly improved compared to that using $\mathrm{RhCl}(\mathrm{CO})(\mathrm{TPPTS})_{2}$ as the sole catalyst $(66.8 \%$ vs $46.1 \%$, Table 1, entries 1 and 4) with slight improvement of conversion.

When the total catalyst concentration and the molar ratio of phosphine to metal were kept constant, the chemoselectivity changed with the variation of molar ratio of $\mathrm{Rh} / \mathrm{Ir}$, as shown in 
Table 1. Both the conversion and selectivity for amines reached optimum values when the molar ratio of $\mathrm{Rh} / \mathrm{Ir}$ was $1: 1$. The regioselectivity for linear amine decreased with the increase of iridium content. The iridium catalyst showed very low activity in the absence of Rh (Table 1, entry 7), although it really promoted the hydroaminomethylation reaction when used together with rhodium, suggesting that the iridium complex was not an effective catalyst for hydroformylation of alkenes.

Table 1. Influence of molar radio of $\mathrm{Rh} / \mathrm{Ir}$ on the hydroaminomethylation of 1-dodecene $\mathrm{a}^{\mathrm{a}}$

\begin{tabular}{cccccccc}
\hline Entry & $\mathrm{Rh} / \mathrm{Ir}$ & $\begin{array}{c}\text { Dodecane } \\
(\%)\end{array}$ & $\begin{array}{c}\text { Isomerized } \\
\text { dodecene } \\
(\%)\end{array}$ & $\begin{array}{c}\text { Aldehyde } \\
(\%)\end{array}$ & $\begin{array}{c}\text { Conversion }^{\mathrm{b}} \\
(\%)\end{array}$ & $\begin{array}{c}\text { Selectivity } \\
\text { for amine } \\
(\%)\end{array}$ & $\begin{array}{c}\mathrm{L} / \mathrm{B}^{\mathrm{c}} \\
\text { (amine) }\end{array}$ \\
\hline 1 & $\mathrm{Rh}$ & 14.2 & 7.3 & 27.9 & 91.4 & 46.1 & 14.6 \\
2 & $4: 1$ & 12.7 & 6.7 & 21.5 & 93.4 & 56.2 & 12.1 \\
3 & $2: 1$ & 12.9 & 6.3 & 17.5 & 93.9 & 60.9 & 10.0 \\
4 & $1: 1$ & 10.5 & 5.2 & 15.5 & 94.0 & 66.8 & 9.6 \\
5 & $1: 2$ & 10.4 & 5.2 & 17.6 & 93.9 & 64.7 & 8.5 \\
6 & $1: 4$ & 12.8 & 6.3 & 15.4 & 91.5 & 62.3 & 7.0 \\
7 & $\mathrm{Ir}$ & 2.6 & 1.0 & 3.4 & 9.2 & 23.3 & 6.3 \\
\hline
\end{tabular}

${ }^{a}$ Reaction conditions: catalyst concentration $(\mathrm{Rh}+\mathrm{Ir}): 1.8 \times 10^{-3} \mathrm{~mol} / \mathrm{l} ;[\mathrm{P}] /[\mathrm{Rh}+\mathrm{Ir}]=30$; dimethylamine: dodecene $=4: 1 ; \mathrm{CTAB}=0.01 \mathrm{~mol} / 1 ; \mathrm{T}=130{ }^{\circ} \mathrm{C} ; \mathrm{P}=3 \mathrm{MPa}\left(\mathrm{CO}: \mathrm{H}_{2}=1: 1\right) ; t=$ $5 \mathrm{~h} .{ }^{\mathrm{b}}$ Conversion: total conversion of 1 -dodecene. ${ }^{c} \mathrm{~L} / \mathrm{B}$ : the ratio of linear- to branched tertiary amine.

In aqueous/organic biphasic system the reaction rate would be reduced largely when the solubility of substrates such as high alkenes in the aqueous phase is low. Biphasic catalysis relies on the transfer of organic substrates into the aqueous phase containing the catalyst or at the interphase. The addition of cationic surfactant, such as cetyltrimethylammonium bromide (CTAB), might enhance the mutual solubility or mobility of the components across the phase boundary to increase the reaction rate. ${ }^{11}$ It can be seen from Table 2 that in the absence of $\mathrm{CTAB}$, the conversion was lower than $30 \%$ within 5 hours. The addition of CTAB increased the reaction rate rapidly, and when the $\mathrm{CTAB}$ concentration was over $1.0 \times 10^{-2} \mathrm{~mol} / \mathrm{l}$ both the conversion and the chemoselectivity did not apparently increase further. This could be explained by the view that the further increase of CTAB concentration could induce the micelle to expand and even to form an $\mathrm{O} / \mathrm{W}$ micro-emulsion in the presence of polar organic compounds. ${ }^{11}$

As shown in Table 3, with the increase of molar ratio of phosphine to metal, both the conversion of 1-dodecene and selectivity for amine increased initially and then decreased, while the regioselectivity for linear product increased continually (entries 1-5). This could be attributed to the ratio of phosphine ligand (L) to metal $(\mathrm{M}=\mathrm{Rh}$, Ir) affecting the coordination equilibrium of catalytic active species. According to the catalytic cycle of hydroformylation, ${ }^{12}$ 
with the increase of the ratio of phosphine ligand to metal, the metal complex converted from $\mathrm{HM}(\mathrm{CO})_{2} \mathrm{~L}$ to $\mathrm{HM}(\mathrm{CO}) \mathrm{L}_{2}$ and then to $\mathrm{HM}(\mathrm{CO}) \mathrm{L}_{3}$, among which $\mathrm{HM}(\mathrm{CO}) \mathrm{L}_{2}$ was the main active species most favorable for the coordination and dissociation of reactants, exhibiting higher catalytic activity. The $\mathrm{HM}(\mathrm{CO}) \mathrm{L}_{3}$ with lower catalytic activity was most favorable for the formation of linear product, owing to the steric effect. ${ }^{13}$

Table 2. Influence of the concentration of CTAB on hydroaminomethylation of 1-dodecene ${ }^{\mathrm{a}}$

\begin{tabular}{cccccccc}
\hline Entry & $\begin{array}{c}\text { Conc. CTAB } \\
\left(10^{-3} \mathrm{~mol} / \mathrm{l}\right)\end{array}$ & $\begin{array}{c}\text { Dodecane } \\
\%\end{array}$ & $\begin{array}{c}\text { Isomerized } \\
\text { dodecene } \%\end{array}$ & $\begin{array}{c}\text { Aldehyde } \\
\%\end{array}$ & $\begin{array}{c}\text { Conv. } \\
\%\end{array}$ & $\begin{array}{c}\text { Selectivity } \\
\text { for amine } \\
\%\end{array}$ & $\begin{array}{c}\text { L/B } \\
\text { Amine }\end{array}$ \\
\hline 1 & 0 & 13.7 & 6.1 & 4.2 & 27.3 & 12.1 & 15.0 \\
2 & 5 & 16.7 & 7.7 & 21.6 & 76.2 & 39.6 & 15.8 \\
3 & 7.5 & 10.9 & 5.5 & 29.4 & 94.1 & 51.3 & 11.4 \\
4 & 10 & 10.5 & 5.2 & 15.5 & 94.0 & 66.8 & 9.6 \\
5 & 15 & 10.5 & 5.0 & 16.0 & 93.1 & 66.2 & 9.8 \\
6 & 20 & 10.3 & 5.3 & 14.7 & 93.8 & 67.7 & 9.1 \\
\hline
\end{tabular}

${ }^{\mathrm{a}}$ Conditions. Catalyst concentration $(\mathrm{Rh}+\mathrm{Ir}) 1.8 \times 10^{-3} \mathrm{~mol} / \mathrm{l} ; \mathrm{Rh} / \mathrm{Ir}=1: 1$; dimethylamine: dodecene $=4: 1 ;[\mathrm{P}] /[\mathrm{Rh}+\mathrm{Ir}]=30 ; \mathrm{T}=130{ }^{\circ} \mathrm{C} ; \mathrm{P}=3 \mathrm{MPa}\left(\mathrm{CO}: \mathrm{H}_{2}=1: 1\right) ; \mathrm{t}=5 \mathrm{~h}$.

The activity and regioselectivity of the hydroaminomethylation reaction in the $\mathrm{Rh} / \mathrm{Ir}$ dualmetal catalytic system is also highly dependent on the temperature and the syngas pressure. The increase of temperature accelerated the formation of catalytic active species and enhanced the reaction activity (Table 3 , entries 6,7 and 3 ), but higher temperature $\left(150{ }^{\circ} \mathrm{C}\right)$ might affect the stability of catalyst and cause partial ligand degradation, leading to decrease of conversion of 1dodecene and selectivity for amine (entry 8). On the other hand, at high temperature, the activation-energy difference for linear- and branched product reduced, which would result in decrease of L/B selectivity. Similarly, the increase of pressure led to an increase of catalytic activity (Table 3, entries 9-11 and 3). However, side- hydrogenation and isomerization of 1dodecene also increased at a pressure above $3 \mathrm{MPa}$, which made the selectivity for amines drop correspondingly (entry 11). By carrying out the reaction at $3 \mathrm{MPa}$ and $130{ }^{\circ} \mathrm{C}$ for 10 hours, the conversion and selectivity for amines reached $97.1 \%$ and $75.1 \%$ respectively.

The effect of the molar ratio of dimethylamine to dodecene on hydroaminomethylation in the $\mathrm{Rh} / \mathrm{Ir}$ dual-metal catalysis system was also examined. The results are shown in Table 4. As in the rhodium catalytic system, ${ }^{7}$ with an increase of the molar ratio of dimethylamine to dodecene, the conversion of 1-dodecene decreased. The chemoselectivity for amine reached the best value at the molar ratio of 4:1 (Table 4, entry 3), showing that a large excess of dimethylamine was unfavorable for hydroformylation. 
Table 3. Hydroaminomethylation of 1-dodecene under various reaction conditions ${ }^{\mathrm{a}}$

\begin{tabular}{cccccccccc}
\hline Entry & $\begin{array}{c}{[\mathrm{P}] /} \\
{[\mathrm{Rh}+\mathrm{Ir}]}\end{array}$ & $\begin{array}{c}\mathrm{T} / \\
{ }^{\circ} \mathrm{C}\end{array}$ & $\begin{array}{c}\mathrm{P} / \\
\mathrm{MPa}\end{array}$ & $\begin{array}{c}\text { Dode- } \\
\text { cane } \%\end{array}$ & $\begin{array}{c}\text { Isomerized } \\
\text { dodecene } \\
(\%)\end{array}$ & $\begin{array}{c}\text { Alde- } \\
\text { hyde } \\
(\%)\end{array}$ & $\begin{array}{c}\text { Conv } \\
\%\end{array}$ & $\begin{array}{c}\text { Selecti- } \\
\text { vity \% for } \\
\text { amine }\end{array}$ & $\begin{array}{c}\mathrm{L} / \mathrm{B} \\
\text { amine }\end{array}$ \\
\hline 1 & 50 & 130 & 3 & 9.1 & 4.9 & 22.4 & 86.7 & 58.0 & 14.2 \\
2 & 40 & 130 & 3 & 8.9 & 4.6 & 21.3 & 93.9 & 62.9 & 10.6 \\
3 & 30 & 130 & 3 & 10.5 & 5.2 & 15.5 & 94.0 & 66.8 & 9.6 \\
4 & 20 & 130 & 3 & 11.2 & 5.3 & 19.7 & 94.9 & 61.9 & 9.5 \\
5 & 10 & 130 & 3 & 14.2 & 6.3 & 15.6 & 91.6 & 60.6 & 9.4 \\
6 & 30 & 90 & 3 & 4.9 & 2.4 & 40.0 & 54.6 & 13.4 & 1.4 \\
7 & 30 & 110 & 3 & 9.2 & 4.9 & 39.6 & 83.3 & 35.5 & 11.1 \\
8 & 30 & 150 & 3 & 19.1 & 9.3 & 3.1 & 87.1 & 63.8 & 4.4 \\
9 & 30 & 130 & 1 & 10.2 & 5.3 & 18.5 & 70.6 & 51.8 & 16.2 \\
10 & 30 & 130 & 2 & 8.2 & 4.8 & 17.1 & 88.9 & 66.1 & 14.4 \\
11 & 30 & 130 & 4 & 16.4 & 8.3 & 15.5 & 91.8 & 56.2 & 9.4 \\
$12^{b}$ & 30 & 130 & 3 & 10.0 & 4.8 & 9.5 & 97.1 & 75.0 & 4.7 \\
\hline
\end{tabular}

${ }^{\mathrm{a}}$ Reaction conditions: Catalyst concentration $(\mathrm{Rh}+\mathrm{Ir}): 1.8 \times 10^{-3} \mathrm{~mol} / \mathrm{l} ; \mathrm{Rh} / \mathrm{Ir}=1: 1, \mathrm{CTAB}=$ $0.01 \mathrm{~mol} / \mathrm{l} ;$ dimethylamine: dodecene $=4: 1 ; \mathrm{CO}: \mathrm{H}_{2}=1: 1 ; \mathrm{t}=5 \mathrm{~h} ;{ }^{b} \mathrm{t}=10 \mathrm{~h}$.

Table 4. Influence of molar ratio of dimethylamine to dodecene on hydroaminomethylation ${ }^{\mathrm{a}}$

\begin{tabular}{cccccccc}
\hline Entry & $\begin{array}{c}\text { Dimethyl- } \\
\text { amine/ } \\
\text { 1-dodecene }\end{array}$ & $\begin{array}{c}\text { Dode- } \\
\text { cane } \\
(\%)\end{array}$ & $\begin{array}{c}\text { Isomerized } \\
\text { dodecene } \\
(\%)\end{array}$ & $\begin{array}{c}\text { Aldehyde } \\
(\%)\end{array}$ & $\begin{array}{c}\text { Conver- } \\
\text { sion } \\
(\%)\end{array}$ & $\begin{array}{c}\text { Selectivity } \\
\text { for amine } \\
(\%)\end{array}$ & $\begin{array}{c}\text { L/B } \\
\text { (amine) }\end{array}$ \\
\hline 1 & $8: 1$ & 21.5 & 9.9 & 3.8 & 82.9 & 57.5 & 4.5 \\
2 & $6: 1$ & 19.3 & 8.7 & 9.2 & 81.7 & 54.5 & 6.7 \\
3 & $4: 1$ & 10.5 & 5.2 & 15.5 & 94.0 & 66.8 & 9.6 \\
4 & $2: 1$ & 10.4 & 5.5 & 22.8 & 94.0 & 58.8 & 16.8 \\
5 & $1: 1$ & 9.7 & 5.1 & 33.6 & 94.6 & 48.8 & 27.2 \\
\hline
\end{tabular}

${ }^{a}$ Reaction conditions: catalyst concentration $(\mathrm{Rh}+\mathrm{Ir}): 1.8 \times 10^{-3} \mathrm{~mol} / \mathrm{l} ; \mathrm{Rh} / \mathrm{Ir}=1: 1 ;[\mathrm{P}] /[\mathrm{Rh}+\mathrm{Ir}]$ $=30 ; \mathrm{CTAB}=0.01 \mathrm{~mol} / \mathrm{l} ; \mathrm{T}=130{ }^{\circ} \mathrm{C} ; \mathrm{P}=3 \mathrm{MPa}\left(\mathrm{CO}: \mathrm{H}_{2}=1: 1\right) ; \mathrm{t}=5 \mathrm{~h}$.

The catalyst concentration is also an important factor in the reaction. In general, a higher catalyst concentration is favorable for the reactivity. However, to our surprise, the increase of catalyst concentration led to a large decrease of conversion, and the chemoselectivity for amine had little variation when the concentration was over $1.8 \times 10^{-3} \mathrm{~mol} / \mathrm{l}$ (Table 5 , entries $1-6$ ). It seems that a high iridium concentration was disadvantageous to the reaction. When the catalyst concentration was kept at $1.0 \times 10^{-2} \mathrm{~mol} / 1$ and the ratio of rhodium to iridium was increased to $9: 1$, 
better reactivity and chemoselectivity were presented, and an excellent selectivity of $87.6 \%$ for amine was obtained (Table 5 , entry 8 ) after 12 hours.

Table 5. Influence of catalyst concentration on hydroaminomethylation of 1-dodecene ${ }^{\mathrm{a}}$

\begin{tabular}{cccccccc}
\hline Entry & $\begin{array}{c}\text { Concentration } \\
\text { of catalyst } \\
(\mathrm{mol} / \mathrm{l})\end{array}$ & $\begin{array}{c}\text { Dodecane } \\
(\%)\end{array}$ & $\begin{array}{c}\text { Isomerized } \\
\text { dodecene } \\
(\%)\end{array}$ & $\begin{array}{c}\text { Aldehyde } \\
(\%)\end{array}$ & $\begin{array}{c}\text { Conversion } \\
(\%)\end{array}$ & $\begin{array}{c}\text { Selectivity } \\
\text { for amine } \\
(\%)\end{array}$ & $\begin{array}{c}\text { L/B } \\
\text { (amine) }\end{array}$ \\
\hline 1 & $0.9 \times 10^{-3}$ & 14.3 & 6.9 & 30.2 & 93.0 & 44.7 & 9.1 \\
2 & $1.8 \times 10^{-3}$ & 10.5 & 5.2 & 15.5 & 94.0 & 66.8 & 9.6 \\
3 & $3.6 \times 10^{-3}$ & 7.1 & 3.9 & 18.5 & 88.0 & 66.5 & 11.2 \\
$4^{2}$ & $5.4 \times 10^{-3}$ & 6.0 & 3.6 & 15.9 & 79.1 & 67.8 & 15.2 \\
5 & $7.5 \times 10^{-3}$ & 5.6 & 3.5 & 13.7 & 68.7 & 66.8 & 18.1 \\
$6^{6}$ & $10 \times 10^{-3}$ & 4.9 & 3.5 & 14.4 & 58.7 & 61.2 & 20.1 \\
$7^{\mathrm{b}}$ & $10 \times 10^{-3}$ & 8.4 & 4.5 & 2.5 & 85.8 & 82.0 & 11.4 \\
$8^{\mathrm{b}, \mathrm{c}}$ & $10 \times 10^{-3}$ & 6.8 & 3.6 & 0.8 & 90.5 & 87.6 & 10.4 \\
\hline
\end{tabular}

${ }^{\mathrm{a}}$ Reaction conditions: $\mathrm{Rh} / \mathrm{Ir}=1: 1 ; \quad[\mathrm{P}] /[\mathrm{Rh}+\mathrm{Ir}]=30 ; \mathrm{CTAB}=0.01 \mathrm{~mol} / \mathrm{l}$; dimethylamine:dodecene $=4: 1 ; \mathrm{T}=130{ }^{\circ} \mathrm{C} ; \mathrm{P}=3 \mathrm{MPa}\left(\mathrm{CO}: \mathrm{H}_{2}=1: 1\right) ; \mathrm{t}=5 \mathrm{~h} .{ }^{\mathrm{b}} \mathrm{Rh} / \mathrm{Ir}=9: 1$. ${ }^{\mathrm{c}} t=12 \mathrm{~h}$.

The catalytic system was applied to the hydroaminomethylation of various other alkenes, and the results are summarized in Table 6 . Compared with the sole use of rhodium complex, ${ }^{7} \mathrm{Rh} / \mathrm{Ir}$ dual-metal catalyst improved the selectivity for amines apparently $(\sim 20 \%)$, but the regioselectivity for linear amines decreased. A significant effect of the alkene chain length on the selectivity was observed. Both the conversion of alkenes and selectivity for amines decreased with the increase of the chain- length of alkenes, which could be attributed to the decreasing solubility of alkenes in aqueous solution. The steric effect of the chain- length led to the higher $\mathrm{L} / \mathrm{B}$ regioselectivity of 1 -dodecene and 1-tetradecene. The activity and the chemoselectivity of 1 hexene hydroaminomethylation were especially higher than other alkenes, but the regioselectivity was drastically decreased. 
Table 6. Hydroaminomethylation of alkenes with different chain lengths ${ }^{\mathrm{a}}$

\begin{tabular}{lcccccc}
\hline Alkenes & \multicolumn{2}{c}{ Rhodium catalyst } & \multicolumn{4}{c}{ Rh/Ir catalyst } \\
& $\begin{array}{c}\text { Conver- } \\
\text { sion (\%) }\end{array}$ & $\begin{array}{c}\text { Selectivity } \\
\text { for amine } \\
(\%)\end{array}$ & $\begin{array}{c}\text { L/B } \\
(\text { amine) }\end{array}$ & $\begin{array}{c}\text { Conversion } \\
(\%)\end{array}$ & $\begin{array}{c}\text { Selectivity for } \\
\text { amine (\%) }\end{array}$ & $\begin{array}{c}\text { L/B } \\
\text { (amine) }\end{array}$ \\
\cline { 2 - 7 } 1-Hexene & 97.1 & 67.8 & 5.5 & 99.2 & 93.2 & 3.5 \\
1-Octene & 95.9 & 42.9 & 9.6 & 97.5 & 75.2 & 4.8 \\
1-Decene & 92.3 & 41.0 & 13.6 & 94.3 & 68.8 & 8.6 \\
1-Dodecene & 92.3 & 42.2 & 15.3 & 94.0 & 66.8 & 9.6 \\
1-Tetradecene & 91.7 & 42.1 & 18.3 & 91.8 & 48.6 & 9.9 \\
\hline
\end{tabular}

${ }^{\mathrm{a}}$ Reaction conditions: catalyst concentration $(\mathrm{Rh}+\mathrm{Ir}): 1.8 \times 10^{-3} \mathrm{~mol} / \mathrm{l} ;[\mathrm{P}] /[\mathrm{Rh}+\mathrm{Ir}]=30$; CTAB $=0.01 \mathrm{~mol} / 1$; dimethylamine: alkene $=4: 1 ; \mathrm{T}=130{ }^{\circ} \mathrm{C} ; \mathrm{P}=3 \mathrm{MPa}\left(\mathrm{CO}: \mathrm{H}_{2}=1: 1\right) ; t=5 \mathrm{~h}$.

\section{Conclusions}

In conclusion, the hydroaminomethylation of dodecene with dimethylamine in aqueous/organic biphasic system by $\mathrm{Rh} / \mathrm{Ir}$ dual- metal catalysis led to higher catalytic activity and especially better chemoselectivity for amine compared to the sole use of rhodium catalyst under similar conditions. Although we did not isolate the intermediate imine or enamine, it could be suggested that the iridium- complex catalyst played active roles in the last hydrogenation reaction of imine or enamine, on the basis of the mechanism proposed in the literature, ${ }^{8,9}$ and thus promoted the reaction. The activity and selectivity of the hydroaminomethylation depended on both the catalyst concentration and the molar ratio of $\mathrm{Rh}$ to Ir. The optimal $\mathrm{Rh} / \mathrm{Ir}$ molar ratio of 1:1 at low catalyst concentration was not suitable for the case where the catalyst concentration was high. The surveyed reactions of other alkenes generally offered good activities, which further proved the efficiency of the dual- metal catalysis system.

\section{Experimental Section}

General Procedures. Catalyst precursors $\mathrm{RhCl}(\mathrm{CO})(\mathrm{TPPTS})_{2}, \operatorname{IrCl}(\mathrm{CO})(\mathrm{TPPTS})_{2}$ and watersoluble phosphine ligand TPPTS were synthesized according to literature procedures. ${ }^{14,15} 1$ Dodecene (Fluka), CTAB (AR) and other reagents (AR) were obtained commercially and were not treated further. Water was doubly distilled. Synthesis gas was obtained by directly mixing carbon monoxide (99.9\%) and hydrogen (99.9\%) in the ratio of $1: 1$.

A general procedure for catalytic hydroaminomethylation follows. The catalyst precursors, TPPTS, CTAB, 1-dodecene and dimethylamine solution were added in a $60 \mathrm{ml}$ stainless steel autoclave equipped with a magnetic stirrer. The autoclave was purged three times with synthesis 
gas and charged to the desired pressure, and then heated to the desired reaction temperature. When the reaction completed, the autoclave was cooled to ambient temperature. The remaining gas was vented. The solution automatically separated into two layers after a few minutes. Products in the organic phase were analyzed by gas chromatograph HP 1890 equipped with an FID (hydrogen flame ionization detector) and a capillary column SE-30 $(30 \mathrm{~m} \times 0.25 \mathrm{~mm})$.

The linear and branched amines were purified by column chromatography (silica gel) for characterization. NMR spectra were recorded on a Varian INOVA $400 \mathrm{MHz}$ or Bruker AC-E $200 \mathrm{MHz}$ NMR spectrometer. Mass spectra (GC -MS) experiments were conducted on an Agilent-6890. High-resolution mass spectra were obtained on a Bruker Daltoics Bio TOF-Q mass spectrometer.

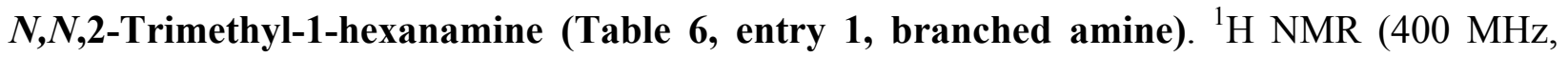
$\left.\mathrm{CDCl}_{3}\right) \delta 2.20(\mathrm{~s}, 6 \mathrm{H}), 1.99-2.10(\mathrm{~m}, 2 \mathrm{H}), 1.55-1.60(\mathrm{~m}, 1 \mathrm{H}), 1.20-1.41(\mathrm{~m}, \mathrm{br}, 5 \mathrm{H}), 1.0-1.1$ $(\mathrm{m}, 1 \mathrm{H}), 0.84-0.94(\mathrm{~m}, 6 \mathrm{H}) .{ }^{13} \mathrm{C} \mathrm{NMR}\left(50 \mathrm{MHz}, \mathrm{CDCl}_{3}\right) \delta 67.1,45.7,34.6,30.7,29.7,29.2$, 23.0, 16.2, 14.1. GC -MS (EI, $70 \mathrm{eV}): m / z=143\left[\mathrm{M}^{+}\right], 97,84,70,58,44,28$. HRMS (ESI) calcd. for: $\mathrm{C}_{9} \mathrm{H}_{21} \mathrm{~N}\left[\mathrm{M}^{+}\right]$143.1674, found $m / z$ 143.1667.

$\boldsymbol{N}, \boldsymbol{N}$-Dimethyl-1-heptanamine (Table 6, entry $\mathbf{1}$, linear amine). ${ }^{16}{ }^{1} \mathrm{H} \mathrm{NMR}\left(400 \mathrm{MHz}, \mathrm{CDCl}_{3}\right)$ $\delta 2.22-2.27(\mathrm{~m}, 8 \mathrm{H}), 1.44-1.48(\mathrm{~m}, 2 \mathrm{H}), 1.24-1.30(\mathrm{~m}, \mathrm{br}, 8 \mathrm{H}), 0.88(\mathrm{t}, J=6.8 \mathrm{~Hz}, 3 \mathrm{H}) .{ }^{13} \mathrm{C}$ NMR (50 MHz, $\left.\mathrm{CDCl}_{3}\right) \delta 59.9,45.4,31.8,29.3,27.7,27.4,22.6,14.0$. GC -MS (EI, $\left.70 \mathrm{eV}\right): \mathrm{m} / z$ $=143\left[\mathrm{M}^{+}\right], 58,42,28$. HRMS (ESI) calcd. for: $\mathrm{C}_{9} \mathrm{H}_{21} \mathrm{~N}\left[\mathrm{M}^{+}\right] 143.1674$, found $m / z 143.1669$.

$\boldsymbol{N}, \boldsymbol{N}$, 2-Trimethyl-1-octanamine (Table 6, entry 2, branched amine). ${ }^{1} \mathrm{H} \mathrm{NMR}(400 \mathrm{MHz}$, $\left.\mathrm{CDCl}_{3}\right) \delta 2.20(\mathrm{~s}, 6 \mathrm{H}), 2.10-1.99(\mathrm{~m}, 2 \mathrm{H}), 1.55-1.60(\mathrm{~m}, 1 \mathrm{H}), 1.20-1.40(\mathrm{~m}, \mathrm{br}, 9 \mathrm{H}), 1.00-$ $1.08(\mathrm{~m}, 1 \mathrm{H}), 0.87-0.92(\mathrm{~m}, 6 \mathrm{H}) .{ }^{13} \mathrm{C} \mathrm{NMR}\left(50 \mathrm{MHz}, \mathrm{CDCl}_{3}\right) \delta 67.1,45.7,35.1,31.7,30.7$, 29.6, 26.9, 22.6, 16.2, 14.0. GC -MS (EI, $70 \mathrm{eV}): m / z=171\left[\mathrm{M}^{+}\right], 58,42,29$. HRMS (ESI) calcd. for: $\mathrm{C}_{11} \mathrm{H}_{25} \mathrm{~N}\left[\mathrm{M}^{+}\right]$171.1987, found $m / z$ 171.1984.

$\boldsymbol{N}, \boldsymbol{N}$-Dimethyl-1-nonanamine (Table 6, entry $\mathbf{2}$, linear amine). ${ }^{1} \mathrm{H} \mathrm{NMR}\left(400 \mathrm{MHz}, \mathrm{CDCl}_{3}\right) \delta$ $2.20-2.25(\mathrm{~m}, 8 \mathrm{H}), 1.38-1.46(\mathrm{~m}, 2 \mathrm{H}), 1.19-1.35(\mathrm{~m}, \mathrm{br}, 12 \mathrm{H}), 0.86(\mathrm{~m}, 3 \mathrm{H}) .{ }^{13} \mathrm{C}$ NMR $(50$ $\left.\mathrm{MHz}_{\mathrm{CDCl}}\right) \delta$ 59.7, 45.4, 31.2, 29.5, 29.5, 29.2, 27.7, 27.4, 22.6, 14.0. GC -MS (EI, $\left.70 \mathrm{eV}\right)$ : $m / z=171\left[\mathrm{M}^{+}\right], 58,42,29$. HRMS (ESI) calcd. for: $\mathrm{C}_{11} \mathrm{H}_{25} \mathrm{~N}\left[\mathrm{M}^{+}\right]$171.1987, found $m / z$ 171.1986.

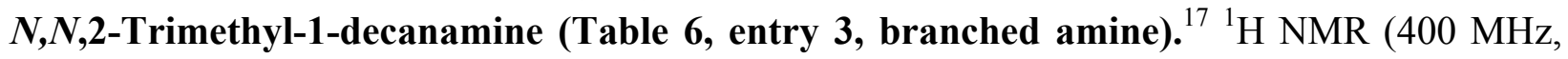
$\left.\mathrm{CDCl}_{3}\right) \delta 2.20(\mathrm{~s}, 6 \mathrm{H}), 1.99-2.10(\mathrm{~m}, 2 \mathrm{H}), 1.55-1.61(\mathrm{~m}, 1 \mathrm{H}), 1.20-1.41(\mathrm{~m}, \mathrm{br}, 13 \mathrm{H}), 1.01-$ $1.10(\mathrm{~m}, 1 \mathrm{H}), 0.86-0.92(\mathrm{~m}, 6 \mathrm{H}) .{ }^{13} \mathrm{C} \mathrm{NMR}\left(50 \mathrm{MHz}, \mathrm{CDCl}_{3}\right) \delta 67.3,45.6,35.2,31.7,31.0$, 30.0, 29.7, 29.3, 27.0, 22.7, 16.2, 14.1. GC -MS (EI, $70 \mathrm{eV}): m / z=199\left[\mathrm{M}^{+}\right], 84,69,58,41,28$. HRMS (ESI) calcd. for: $\mathrm{C}_{13} \mathrm{H}_{29} \mathrm{~N}\left[\mathrm{M}^{+}\right]$199.2300, found $m / z$ 199.2311.

$\boldsymbol{N}, \boldsymbol{N}$-Dimethyl-1-undecanamine (Table 6, entry 3, linear amine). ${ }^{17}{ }^{1} \mathrm{H}$ NMR (400 $\mathrm{MHz}$, $\left.\mathrm{CDCl}_{3}\right) \delta 2.21-2.25(\mathrm{~m}, 8 \mathrm{H}), 1.43-1.47(\mathrm{~m}, 2 \mathrm{H}), 1.22-1.36(\mathrm{~m}, \mathrm{br}, 16 \mathrm{H}), 0.88$ (t, $J=6.8 \mathrm{~Hz}$, $3 \mathrm{H}) .{ }^{13} \mathrm{C} \mathrm{NMR}\left(50 \mathrm{MHz}, \mathrm{CDCl}_{3}\right) \delta 59.9,45.5,31.7,29.6,29.3,27.8,27.5,22.6,14.1 . \mathrm{GC}-\mathrm{MS}$ (EI, $70 \mathrm{eV}): m / z=199\left[\mathrm{M}^{+}\right], 84,58,41,28$. HRMS (ESI) calcd. for: $\mathrm{C}_{13} \mathrm{H}_{29} \mathrm{~N}\left[\mathrm{M}^{+}\right]$199.2300, found $\mathrm{m} / \mathrm{z} 199.2314$. 


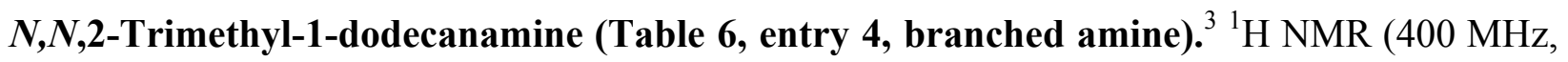
$\left.\mathrm{CDCl}_{3}\right) \delta 2.20(\mathrm{~s}, 6 \mathrm{H}), 1.99-2.10(\mathrm{~m}, 2 \mathrm{H}), 1.55-1.60(\mathrm{~m}, 1 \mathrm{H}), 1.22-1.40(\mathrm{~m}, \mathrm{br}, 17 \mathrm{H}), 0.98-$ $1.10(\mathrm{~m}, 1 \mathrm{H}), 0.81-0.89(\mathrm{~m}, 6 \mathrm{H}) .{ }^{13} \mathrm{C} \mathrm{NMR}\left(50 \mathrm{MHz}, \mathrm{CDCl}_{3}\right) \delta$ 67.3, 45.6, 35.1, 31.7, 31.0, 30.0, 29.6, 29.3, 27.0, 22.6, 16.2, 14.1. GC -MS (EI, $70 \mathrm{eV}): m / z=227\left[\mathrm{M}^{+}\right], 84,69,58,41,28$. HRMS (ESI) calcd. for: $\mathrm{C}_{15} \mathrm{H}_{33} \mathrm{~N}\left[\mathrm{M}^{+}\right]$227.2613, found $\mathrm{m} / \mathrm{z} 227.2601$.

$\boldsymbol{N}, \boldsymbol{N}$-Dimethyl-1-tridecanamine (Table 6, entry 4, linear amine). ${ }^{3}{ }^{1} \mathrm{H}$ NMR (400 $\mathrm{MHz}$, $\left.\mathrm{CDCl}_{3}\right) \delta 2.22-2.27(\mathrm{~m}, 8 \mathrm{H}), 1.44-1.47(\mathrm{~m}, 2 \mathrm{H}), 1.25-1.32(\mathrm{~m}, \mathrm{br}, 20 \mathrm{H}), 0.88(\mathrm{t}, J=6.8 \mathrm{~Hz}$, $3 \mathrm{H}) .{ }^{13} \mathrm{C} \mathrm{NMR}\left(50 \mathrm{MHz}, \mathrm{CDCl}_{3}\right) \delta 59.7,45.4,31.7,29.6,29.3,27.8,27.5,22.7,14.1 . \mathrm{GC}-\mathrm{MS}$ (EI, $70 \mathrm{eV}): m / z=227\left[\mathrm{M}^{+}\right], 84,70,58,41,28$. HRMS (ESI) calcd. for: $\mathrm{C}_{15} \mathrm{H}_{33} \mathrm{~N}\left[\mathrm{M}^{+}\right] 227.2613$, found $\mathrm{m} / \mathrm{z} 227.2608$.

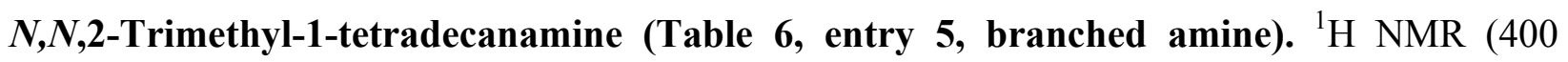
$\left.\mathrm{MHz}, \mathrm{CDCl}_{3}\right) \delta 2.17(\mathrm{~s}, 6 \mathrm{H}), 1.97-2.07$ (m, 2H), $1.53-1.58(\mathrm{~m}, \mathrm{br}, 2 \mathrm{H}), 1.16-1.48$ (m, br, 19H), $0.97-1.06(\mathrm{~m}, 2 \mathrm{H}), 0.85-0.89(\mathrm{~m}, 6 \mathrm{H}) .{ }^{13} \mathrm{C} \mathrm{NMR}\left(50 \mathrm{MHz}, \mathrm{CDCl}_{3}\right) \delta 67.3,45.9,35.2$, 31.9, 31.0, 30.0, 29.7, 29.4, 27.0, 22.7, 16.2, 14.1. GC -MS (EI, $70 \mathrm{eV}): m / z=255\left[\mathrm{M}^{+}\right], 86,69$, 58, 43, 28. HRMS (ESI) calcd. for: $\mathrm{C}_{17} \mathrm{H}_{37} \mathrm{~N}\left[\mathrm{M}^{+}\right]$255.2926, found $m / z$ 255.2932.

$\boldsymbol{N}, \boldsymbol{N}$-Dimethyl-1-pentadecanamine (Table 6, entry 5, linear amine). ${ }^{1} \mathrm{H} \mathrm{NMR}(400 \mathrm{MHz}$, $\left.\mathrm{CDCl}_{3}\right) \delta 2.21-2.26(\mathrm{~m}, 8 \mathrm{H}), 1.42-1.46(\mathrm{~m}, 4 \mathrm{H}), 1.22-1.32(\mathrm{~m}, \mathrm{br}, 22 \mathrm{H}), 0.87(\mathrm{t}, J=6.8 \mathrm{~Hz}$, $3 \mathrm{H}) .{ }^{13} \mathrm{C} \mathrm{NMR}\left(50 \mathrm{MHz}, \mathrm{CDCl}_{3}\right) \delta 59.7,45.4,31.6,29.6,29.3,27.7,27.4,22.6,14.0 . \mathrm{GC}-\mathrm{MS}$ (EI, $70 \mathrm{eV}$ ): $m / z=255\left[\mathrm{M}^{+}\right], 86,69,58,43,28$. HRMS (ESI) calcd. for: $\mathrm{C}_{17} \mathrm{H}_{37} \mathrm{~N}\left[\mathrm{M}^{+}\right] 255.2926$, found $\mathrm{m} / \mathrm{z} 255.2922$.

\section{References}

1. Ricci, A., Ed., Modern Amination Methods, Wiley -VCH: Weinheim, Germany, 2000; p 1.

2. Müller, T. E.; Beller, M. Chem. Rev. 1998, 98, 675.

3. Schulte, M. M.; Herwig, J.; Fischer, R. W.; Kohlpaintner, C. W. J. Mol. Catal. A: General 1999, 150, 147.

4. Joó, F.; Kathó, A. J. Mol. Catal. A: General 1997, 116, 3.

5. Hermann, W. A.; Cornils, B. Angew. Chem. Int. Ed. Engl. 1997, 36, 1048.

6. Zimmermann, B.; Herwig, J.; Beller, M. Angew. Chem. Int. Ed. Engl. 1999, 38, 2372.

7. Wang, Y.; Luo, M.; Li Y.; Chen, H.; Li X. Appl. Catal. A: General 2004, 272, 151.

8. Reppe, W.; Kindler, H. Liebigs Annalen 1953, 582, 148.

9. Baig, T.; Molinier, J.; Kalck, P. J. Organomet. Chem. 1993, 455, 219.

10. Chan, Y. N. C.; Meyer, D.; Osborn, J. A. J. Chem. Soc., Chem. Commun. 1990, 12, 869.

11. Chen, H.; Li Y.; Chen, J.; Cheng, P.; Li, X. J. Mol. Catal. A: General 2003, 198, 1.

12. Chen, H.; Li Y.; Li, R.; Cheng, P.; Li, X. Catal. Today 2002, 74, 131.

13. Chen, H.; Liu, H.; Li, Y.; Cheng, P.; Li, X. J. Mol. Catal. (China) 1994, 8, 124.

14. Chen, H.; Li, X.; Liu, H.; Li, Y. Chinese Patent 1179428, 1998; Chem. Abstr. 1998, 132, 78689. 
15. Chen, H.; Li, Y.; Cheng, P.; Li, X. J. Mol. Catal. (China) 1993, 7, 377.

16. Bhattacharyya, S. J. Org. Chem. 1995, 60, 4928.

17. Jachimowicz, F.; Raksis, J. W. J. Org. Chem. 1982, 47, 445. 